Discourse and Communication for Sustainable Education, vol. 12, no. 1, pp. 5-21, 2021

\title{
How to Bring About Change - A Literature Review About Education and Learning Activities for Sustainable Development
}

\author{
Beatrix Algurén \\ University of Gothenburg, Göteborg, Sweden
}

\begin{abstract}
Sustainable development and transformational change have become more critical than ever in the era of climate change. The aim of this literature review was to increase knowledge on education and learning activities (ELAs), along with the learning outcomes they address, in the context of higher education for sustainable development (SD) with UNESCO's eight core competencies for SD as a starting point. The search was conducted in two educational databases, Education Research Complete and the Education Resource Information Center. 153 articles were identified, of which 16 remained after reviewing for inclusion and exclusion criteria. Education and learning activities in ESD were grounded in discussions, reflections and interdisciplinarity by using participatory teaching methods, such as problem-based or experiential learning. Commonly enhanced learning outcomes were knowledge, attitude and collaboration competencies, as well as critical and system thinking. Self-awareness and behavior change, however, were less frequently achieved and the studies addressing behavior frequently recognized inertia to behavior change, despite transferred attitudes and increased knowledge. Although UNESCO outlined behavioral learning objectives as particularly important for ESD, the present review revealed that these had hardly been reached by the used ELA. The paper discusses the complexity of behavior change and proposes an ethics-led and whole-institution approach to tackle some challenges for behavioral action and social activity. There is a need for new educational and learning activities, which have greater transformational potential, by acknowledging the complexity of behavior change.
\end{abstract}

Key words: behavior, change, complexity, learning, education, transformational, selfawareness, sustainability

\section{Introduction}

Sustainable development (SD) and transformational change have become more important than ever in order to tackle the worldwide life-threatening climate change. Questions concerning climate research are no longer solely focused on the climate problem, but more on how rapid and transformational change of society can be achieved to prevent a dangerous level of global warming (Fazey et al., 2018). With the United Nations 
(UN) World Summit in Rio de Janeiro in 1992, the role of education for SD was put conspicuously on the international political agenda. The importance of ESD was further stressed with the proclamation of the World Decade on education for sustainable development (ESD) between the years 2005 to 2014 (UNESCO, 2014b). To advance the educational activities, the Global Action Programme (GAP) was launched in 2014 with five key elements among others to "promote whole-institution approaches to ESD at all levels and in all settings" and to "strengthen the capacity of educators, trainers and other change agents to become learning facilitators for ESD” (UNESCO, 2014a). Some countries went further and emphasized the role of education for SD in their local SD strategies, like the United Kingdom's strategy, that argues for sustainable development principles as the core of the education system and sustainability literacy as a core competence among graduates (Dawe, Jucker, \& Martin, 2005; Salite, 2015; Heasly et al., 2020; Salite et al., 2020).

\section{Principles and Learning Outcomes of ESD}

The goal of ESD goes beyond seeking to achieve understanding of sustainability problems, but rather aims to find solutions for them (Barth \& Michelsen, 2013; Wals \& Jickling, 2002). Learning outcomes and key competencies that students should acquire in ESD are systems thinking, anticipatory (pre-visional), normative, strategical and interpersonal competencies, as identified by a broad review from Wiek, Withycombe and Redman (2011). In 2017, the United Nations Educational, Scientific and Cultural Organization (UNESCO) (2017) formalized and further developed this set of core competencies into a final number of eight: a) systems thinking competency, b) anticipatory competency, c) normative competency, d) strategic competency, e) collaboration competency, f) critical thinking competency, g) self-awareness competency, h) integrated problem-solving competency. In order to act and achieve change, UNESCO (2018) outlined especially the cognitive (knowledge), socio-emotional (interpersonal and motivational) and behavioral (actional and promotive) learning objectives as important. Learning approaches with active and experiential design, which combine cognition, perception, behavior and experience, are therefore highly valued for ESD, and can empower individuals for critical self-reflection in the societal context, thus leading to reflective and responsible actions (Clark \& Dickson, 2003; Wiek et al., 2011; Wiek, Xiong, Brundiers, \& van der Leeuw, 2014; Pipere, 2019).

\section{Active Learning and Education Approaches}

One common active learning approach is problem-based learning (PBL). It has been influenced by cognitive psychology and its roots can be found in Dewey's (1929) idea of fostering children as independent learners and in Bruner's (1959) belief of intrinsic motivation as the internal motor of individuals for continuously seeking knowledge. The problem as a starting point of learning is also credited to Dewey's idea that learning occurs in response to, and in interaction with, real-life events. Despite slight variations of PBL in the literature, there are some common characteristics: a) learning starts with and occurs through engagement with a real-life problem, b) students are introduced to the problem prior to being taught the necessary knowledge, e.g. they start with what they know and actively seek the necessary information themselves around problems 
rather than disciplines, c) active learning takes place by the application of teamwork and group interaction supported by facilitators (Vardi \& Ciccarelli, 2008). This learning approach clearly seems to have potential to influence students and to reach education goals for SD.

Another common concept of active learning is experiential learning. Experiential learning was introduced by psychologist and educational theorist Kolb (1984) and concentrated on the process of "learning by doing" and the concrete experience from which learning can be initiated, reviewed, challenged and reconsidered (Fry, Ketteridge, \& Marshall, 1999). The theory originates in the earlier works of Dewey with his philosophical pragmatism, Lewin with his social psychology and Piaget with his cognitive developmental genetic epistemology. Three major traditions are common for experiential learning: a) learning is best conceived as a process, not in terms of outcomes; b) learning is a continuous process grounded in experience, $\mathrm{c}$ ) the process of learning requires the resolution of conflicts between dialectically opposed modes of adaptation to the world (Kolb, 1984). While PBL starts with a real-world problem, experiential learning starts with an actual or concrete experience (Kolb, 1984). Thus, the students are engaged more actively. Similar to PBL, within experiential learning, students need the opportunity to reflect, discuss and process the experience. This process is visualized in Kolb's (1984) experiential learning cycle with the four stages: a) concrete experience (a new experience is encountered or an existing experience is re-interpreted), b) reflective observation (are there any inconsistencies between experience and understanding?), c) abstract conceptualization (that gives rise to a new idea or an existing abstract concept - the person as learned from their experience), and d) active experimentation (the learner applies their ideas to the world around them). In that way, learning can be defined as the process "whereby knowledge is created through the transformation of experience" and is action-oriented (Kolb, 1984, p. 38).

Experiential learning theory diverges from cognitive theories of learning and from behavioral learning theories. While cognitive theories have a tendency to focus on memorizing, acquisition and manipulation, behavioral learning theories are based on empirical epistemology and neglecting the role for consciousness and subjective experience. In contrast, experiential learning theory advocates a holistic integrative perspective on learning and combines cognitive and behavioral theory perspectives into one with recognition of experience, perception, cognition and behavior (Kolb \& Boyatzis, 2000). A recent meta-analysis of the relationship between experiential learning and learning outcomes showed a positive effect on superior learning outcomes and examination marks (Burch et al., 2019).

Both PBL and experiential learning could be promising approaches for ESD. However, little is known about what kind of education and learning activities (ELAs) are used in ESD and how they advance students' learning outcomes, such as knowledge, competencies, attitudes, values and behavior, which were particularly emphasized by UNESCO (UNESCO, 2014b). The field of ESD is still a relatively new approach to learning and the concept and principles of ESD are not yet well implemented in higher education (Mulà et al., 2017). Thus, the aim of this literature review was to increase knowledge on ELAs in the context of higher education for sustainable development through two specific research questions: a) what kind of ELAs are used and b) which learning outcomes out of UNESCO's eight core competencies for SD were addressed? 


\section{Research Methodology}

The literature review was conducted in the year 2019 with searches in the two education and teaching-focused databases Education Research Complete and the Education Resource Information Center (ERIC). The search was limited to the time period between January 2010 and May 2019 in order to capture the latest state of the art. Search terms were identified by the model of PICOS, P (population), I (intervention), C (control group/comparison), O (outcome), S (study type) (Moher, Liberati, Tetzlaff, Altman, \& Group, 2009). The 'population' of interest was limited to students within the context of higher education and university, whereas the 'intervention' was education and learning for SD. Search terms for 'outcomes' were identified through UNESCO's (2017) eight key competencies for SD. Overview of the search strategy along with results can be found in Table 1.

Table 1

Overview of Search Strategy

\begin{tabular}{|c|c|c|c|c|c|}
\hline Search & PICOS & Search terms & $\begin{array}{l}\text { Combined } \\
\text { with }\end{array}$ & $\begin{array}{l}\text { Searched } \\
\text { in }\end{array}$ & $\begin{array}{c}\text { Results } \\
\mathrm{N}\end{array}$ \\
\hline$\# 1$ & Population & $\begin{array}{l}\text { Higher education } \\
\text { University* }\end{array}$ & OR & abstract & 399330 \\
\hline \multirow[t]{2}{*}{$\# 2$} & Intervention & $\begin{array}{l}\text { Education for sustainable } \\
\text { development } \\
\text { Education for sustainability } \\
\text { Learning for sustainable develop- } \\
\text { ment } \\
\text { Learning for sustainability } \\
\text { Education and learning for } \\
\text { sustainable development } \\
\text { Education and learning for } \\
\text { sustainability }\end{array}$ & OR & text & 5488 \\
\hline & $\begin{array}{l}\text { Control group/ } \\
\text { Comparison }\end{array}$ & $\begin{array}{l}\text { Not applicable for research } \\
\text { question }\end{array}$ & & & \\
\hline$\# 3$ & Outcome & $\begin{array}{l}\text { System* thinking } \\
\text { Anticipatory } \\
\text { Normative } \\
\text { Strategic } \\
\text { Collaboration } \\
\text { Critical thinking } \\
\text { Self-awareness } \\
\text { Integrated problem-solving } \\
\text { Competenc* }\end{array}$ & OR & abstract & 105532 \\
\hline \#4 & Study design & $\begin{array}{l}\text { Unspecified } \\
\# 1 \# 2 \# 3\end{array}$ & AND & & 153 \\
\hline
\end{tabular}

\section{Data Extraction and Analysis}

The results of 153 studies were downloaded to Excel and screened on abstract level for inclusion criteria, namely the studies' topic being about a) ELA for SD in higher 
education (university) and b) about learning for sustainable development. Studies were excluded if they did not meet inclusion criteria or were about a) curricula specific/ framework for ESD, b) prerequisites for ESD, and c) if not written in English. Full-text screening was done for the 30 eligible articles, of which 14 articles were further excluded (see flow-diagram in Figure 1). The final 16 articles were analyzed thematically in line with the two research questions, with one theme being 'education and learning activities' and another 'students' competencies. Additionally, background information of the studies, such as number of participants, discipline/subject, country and research methods/analysisunits were extracted. Study findings that did not fit to any of the themes, but were relevant for answering the research questions, were extracted and listed under 'comments.'

\section{Figure 1}

The Flow Diagram for Article Extraction With the Final Number of Articles (N = 16) Included for the Thematic Analysis

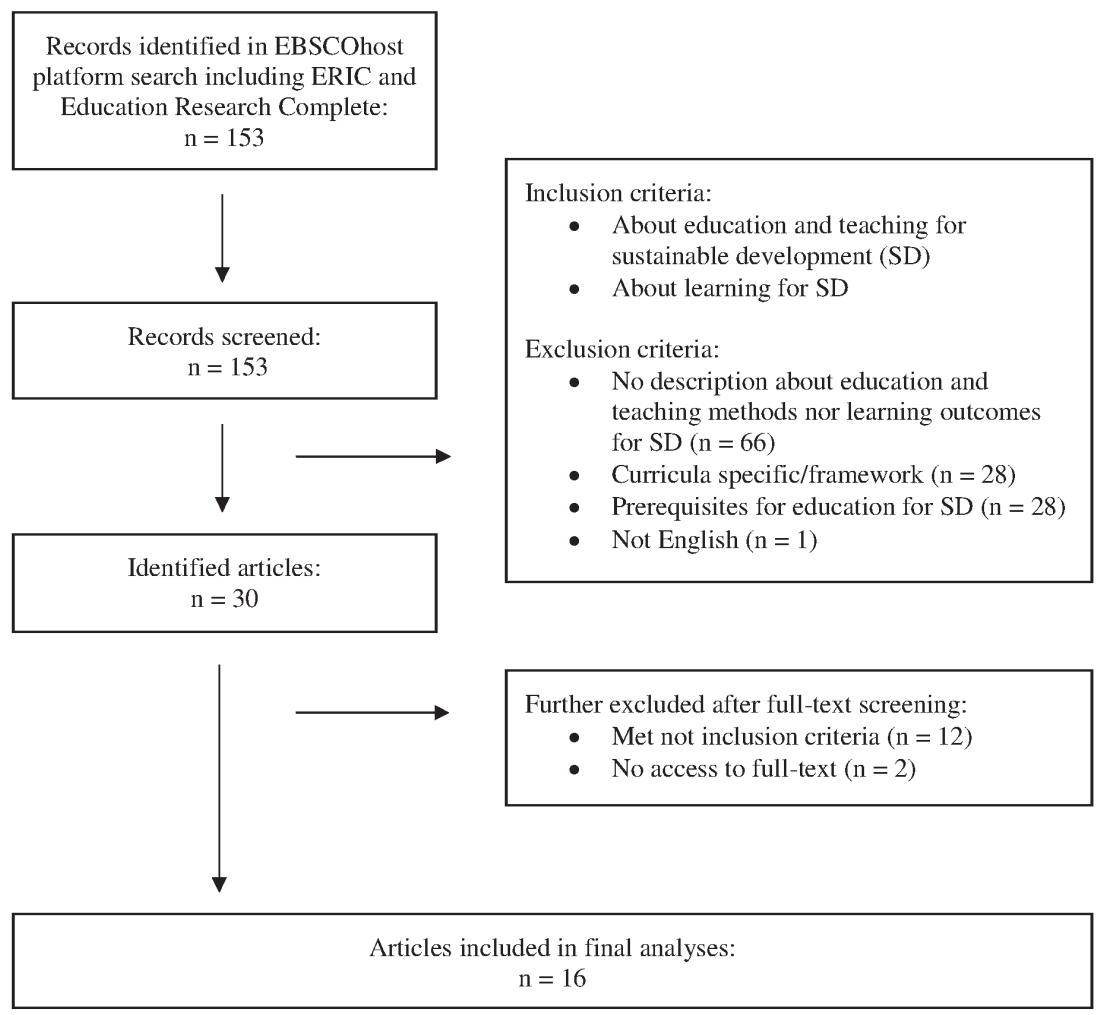

\section{Research Findings}

The characteristics of the included studies are summarized prior to presentation of the findings, firstly, by what ELA were used and, secondly, by what learning outcomes were addressed.

The subject field of environment and architecture $(n=7)$ was most common among the 16 articles. Five articles were subject-unspecific, but included multiple disciplines 
$(\mathrm{n}=5)$, two were from the field of teacher training and one article was from the textile and apparel field. Most studies were performed in the United States ( $n=7)$, but some were done in collaboration with several countries $(n=3)$. Sample size varied from 6 participants (Ellis \& Weekes, 2008) to 1973 participants (Altomonte, Logan, Feisst, Rutherford, \& Wilson, 2016). Students' learning outcomes were investigated by qualitative and quantitative methods, using surveys and questionnaires $(\mathrm{n}=5)$, individual interviews and focus-group interviews $(\mathrm{n}=6)$, document analysis including students' examinations and written reports $(n=6)$, observation $(n=2)$ and one study used ethnographic methods. See more detailed information about the included studies in Appendix Table 1.

\section{Education and Learning Activities}

Table 2 gives an overview of the used ELAs and the learning outcomes addressed in the included studies. Each study combined multiple ELAs, of which discussion, reflections and interactivity were generic characteristics for all. No courses were conducted solely through frontline lecturing, but students were actively involved and requested to think, reflect and argue aloud. Half of the studies included collaboration with stakeholders from the field and/or collaboration with persons from different disciplines. For example, Altomonte et al. described the development and use of the EDUCATE online portal (www.educate-sustainability.eu), to promote ESD in the curricula of built environment. It involved several academic partners, but also building practitioners (Altomonte et al., 2016). In the study from Belluigi and Cundill, interdisciplinarity was achieved by the diversity of students' background in the class from natural science, social science and commerce (Belluigi \& Cundill, 2017).

Other common ELA characteristics were the approach of experiential learning $(\mathrm{n}=8)$ and problem-based learning $(\mathrm{n}=7)$. Distinction between these two concepts was sometimes neglected, which might be due to their overlapping content. Interdisciplinarity, as well as experiential learning, were applied within the course 'Engineering for Developing Communities' described by Mintz et al. (Mintz, Talesnick, Amadei, \& Tal, 2014). During the four-week course, students were taught each day by tutors form various disciplines, such as civil engineers, a medical doctor, an archeologist and an anthropologist. Students were also divided into teams and assigned to a Bedouin village in which they needed to apply their newly gained tools to solve complex problems in a real community. Students were further asked to apply methods of participatory research to gain insights of the improvement processes. Problem-based learning activities, in turn, were used in the study from Abner et al. within a sustainability course as part of a textile and apparel program (Abner, Baytar, \& Kreiner, 2019). By various assignments, students investigated and critically evaluated the environmental impact of different garments and presented ideas on how to detect greenwashing.

Two studies included role-play pedagogy (do Amaral \& Hess, 2018; Gordon \& Thomas, 2018). While Admaral introduced role-playing via a free multiplayer, a webbased simulation game called FISHBANKS, Gordon and Thomas used the more traditional version with students engaged as presenters and as part of a panel of stakeholders at a symposium playing their roles and defending their specific point of view (See Table 2 in the attachment). 


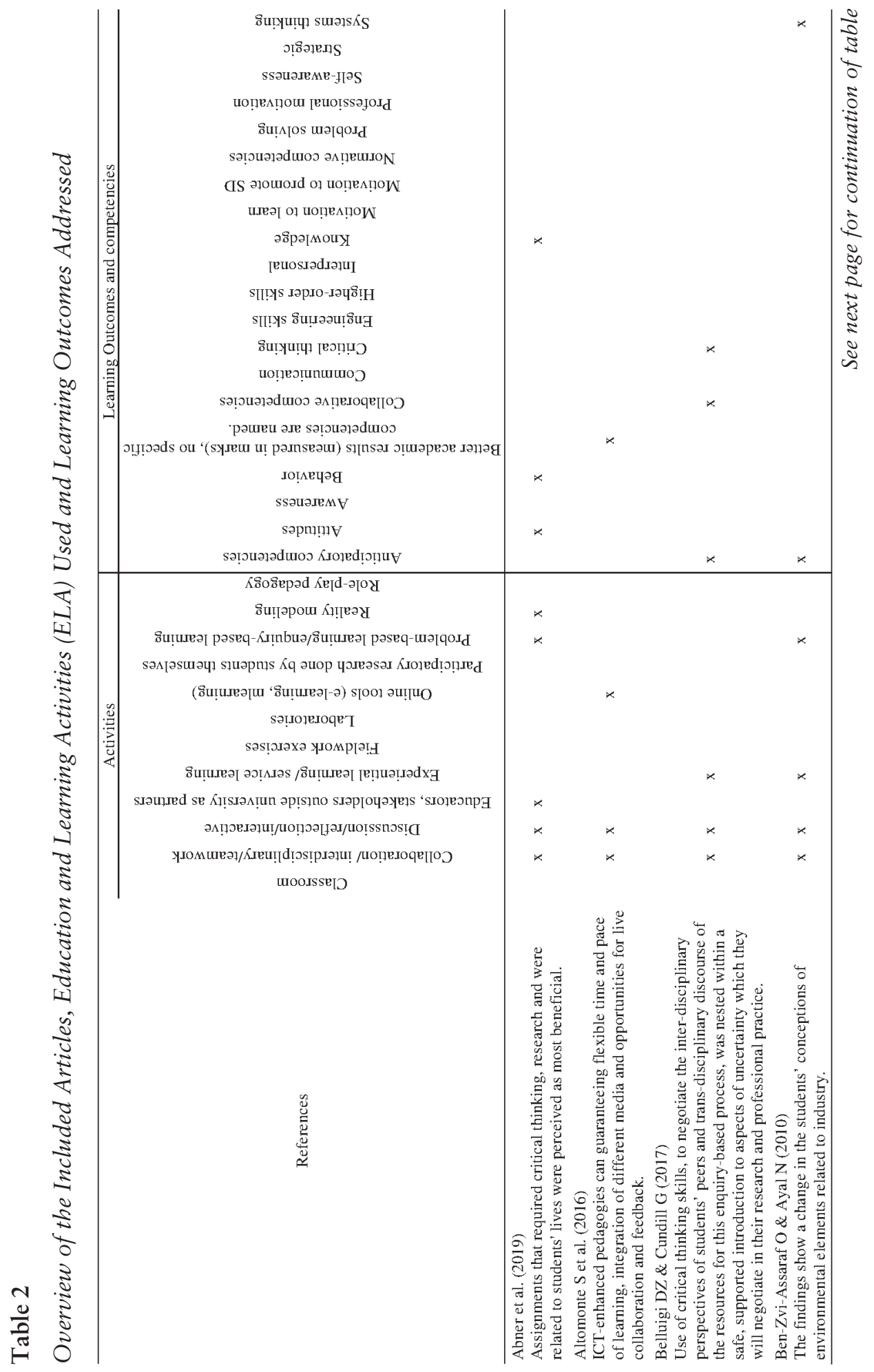




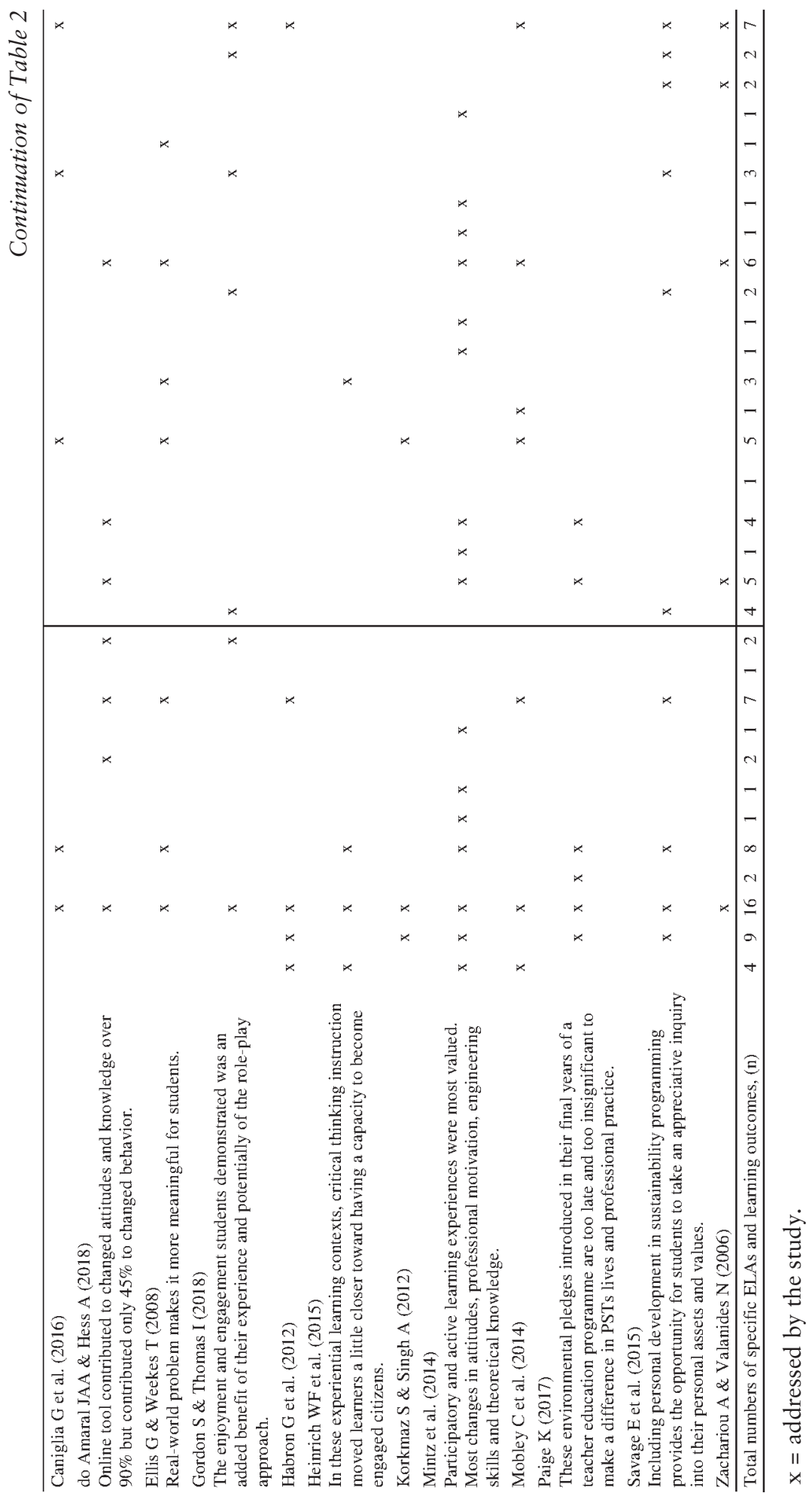




\section{Students' Learning Outcomes}

The studies focused on various learning outcomes and most of them addressed multiple outcomes. Competencies of systems thinking were most commonly evaluated $(\mathrm{n}=7)$, followed by knowledge $(\mathrm{n}=6)$, as well as attitudes and collaboration competencies $(\mathrm{n}=5)$. Knowledge could be about sustainable development itself, but also about professional knowledge in relation to sustainability. Anticipatory competencies and behavior were studied less frequently $(n=4)$ and only three studies addressed (self-) awareness and normative competencies.

Three studies evaluated critical thinking competencies and these competencies were used partly as an umbrella concept along with other learning outcomes. Heinrich et al., for instance, evaluated critical thinking competencies, but included in that concept systemthinking competencies as well (Heinrich, Habron, Johnson, \& Goralnik, 2015). While Mintz et al. focused on motivation - motivation to learn about and to promote SD (Mintz et al., 2014), Altomonte et al. aimed to measure change in marks without refilling the content of examination (Altomonte et al., 2016).

Overall, the described ELA developed students' SD competencies as concluded by the authors of the included articles. Some studies measured that effect by a longitudinal design with pre-post questionnaire, for example Abner et al. and Mintz et al. (Abner et al., 2019; Mintz et al., 2014). Others identified that by interviews (in-depth, focus group), observation, analysis of personal reports or ethnographic methods. Results across all studies revealed, that students appreciated the real-problem experience and collaboration with stakeholders and different professions as most valuable for their learning. A common conclusion among the four behavior studies was that the ELAs increased mainly attitudes and knowledge towards SD, but had lesser impact on behavior change (Abner et al., 2019; do Amaral \& Hess, 2018; Mintz et al., 2014; Paige, 2017).

\section{Discussion}

By looking closer at what kind of education and learning methods are used within higher education and what impact they have on students' competencies and behavior towards sustainable development, the present literature review revealed some generic ELA. Discussion, reflection and interactivity were fundamental components of ESD and were often used in combination with problem-based or experiential learning activities. Most studies adapted the principles of teaching activities through a holistic perspective and heads-on, hands-on, hearts-on approach in order to promote student's engagement and achieve transformative change, which is particularly needed for SD (Sipos, Battisti, \& Grimm, 2008). UNESCO (2018) pointed out that the education process should include: a) situated relevance (a real-life problem that is located and connected to the student), b) co-engaged (together rather than top-down learning), learning-led change (e.g. developing understanding where learning together about the topic leads to greater understanding and action), c) action learning networks: groups of people actively learning and taking action together through connected networks, d) ethics-led whole-institution change projects: where learning is led by values and the whole institution is involved in changing the situation so that it is more sustainable (p. 130). 
The identified studies commonly addressed most of the UNESCO's attributes named above, such as starting with a real-life problem and active learning with interaction and co-engagement by using the methods of PBL or experiential learning. Learning and taking action through connected networks was accomplished through involvement of stakeholders from the community and by bringing real-life problems into academia to figure out solutions together. Time for reflection and discussion were essential features in order to make learning happen. By using PBL and experiential learning methods, students were active and engaged participants in their learning activities and in line with UNESCO's recommendation to use participatory teaching and learning methods for ESD (UNESCO, 2018).

While all the included studies used some kind of participatory teaching method, teaching activities could differ. For example, Mintz et al. (2014) used participatory research done by students as an ELA itself, Altomonte et al. (2016) and Amaral and Hess (2018) used online learning tools, whereas Gordon and Thomas (2018) and Amaral and Hess used role-play pedagogy (2018). Forms for assessment could be traditional exams with multiple choice questions or essays, but also concrete solutions for a problem. Repeatedly, active and participatory learning in the real world were highly appreciated by students for their learning outcomes.

The competencies that students developed comprised the core competencies for $\mathrm{SD}$, such as critical thinking, systems thinking, anticipatory, normative, strategical and interpersonal competencies. Behavior transformation, however, which is so important for SD, was less frequently achieved. UNESCO stressed the need for empowered learners that could make informed decisions and take responsible actions to transform the world (2018) and suggested that transformational education was important for ESD. Transformational education is remarkably similar to Kolb's experiential learning theory, but makes the role of individuals and their understanding of themselves (psychological), the revision of individuals' belief systems (convictional), and the change of individual action in response to their physical environment (behavioural), even more explicit (Mezirow, 1997).

In order to be able to address behavior change, it is important to understand the complexity of behavior change itself. Behavior change has a strong temporal dimension and should not be seen as a discrete event, but rather as a process over time. Prochaska and DiClemente (1998) identified six stages of change and described these six stages in Proschaska's transtheoretical model of change (TTMC) with precontemplation, contemplation, preparation, action, maintenance, and termination. All these stages can occur in a progressive linear manner (DiClemente \& Prochaska, 1982). However, at each stage the risk exists for relapse to a lower stage except at the final stage of termination where the new behavior has become automatic with 100 percent self-efficacy. Furthermore, in order to explain how and why people move from stage to stage, ten processes of change are specified: 1) consciousness raising, 2) dramatic relief, 3) self-reevaluation, 4) environmental reevaluation (social and physical), 5) self-liberation, 6) social liberation, 7) counterconditioning, 8) stimulus control, 9) contingency management and 10) helping relationships (DiClemente \& Prochaska, 1982). These sub-processes can be seen as the activities that people use evidently or un-evidently to advance through the stages and finally be able to succeed with a new internalized behavior. They are based in traditions from Freud (1959) with consciousness raising, from Skinner (1971) with contingency management and from Rogers (1951) with helping relationships. Experiential and transforma- 
tional learning theories that are highly valuated in ESD try to address some of these processes like consciousness raising, building relationships and networks, or environmental reevaluation. However, the present literature review revealed that ESD dealt less frequently with self-awareness ( 3 out of 16 studies) and individual behaviors ( 4 out of 16 studies). In 2015, Fischer et al. concluded from a literature review that a holistic approach to education, which sees the body, heart and mind as a whole embedded within a living system with society and nature, was promising and important for ESD, since it can promote self-awareness (Fischer et al., 2015). Fischer et al. further assumed that this approach has the potential to enhance the transformation of the educational system as a whole, which is necessary for ESD. Despite the fact that UNESCO prioritized an ethics-led whole-institution approach to ESD (UNESCO, 2014a), none of the studies included in this review reported on this point. Keeping in mind the complexity of behavior change, a whole-institution approach could facilitate behavior change more effectively by supporting individuals continuously and repeatedly over a longer time period throughout the programme, as compared to the potential of an individual course of a shorter duration, thus helping students go through the TTMC's stages of behavior necessary for sustainable transformation of individuals' actions.

A recent study from 2019 on students' reflections on their readiness for social activity in climate change showed that students felt only moderately ready to change (Harmoinen, Koivu, \& Pääsky, 2020). Especially important for change was creating an atmosphere where taking actions was positively highlighted and stimulated through evidence-based knowledge and without blaming each other. Building this kind of atmosphere through trustworthiness and societal responsibility, and without threatening individual freedom, might be more effectively achieved by a whole-institution approach, rather than by one course. Such an approach would ensure consistent communication about climate change through at least three years of higher education.

This literature review has some limitations. Firstly, search terms were restricted to appear in title or abstract. This was done because of the otherwise huge number of articles using "sustainable development" in any field of their articles, but were not specifically about ELA. Secondly, the literature review is not as stringent as a systematic literature review with quality review of the included articles. In the jungle of sustainable literature across different disciplines with different methodologies and reporting styles, it was hard to be rigorous in quality assessment. Thus, the present literature review claims not to be comprehensive, but a first attempt to fill the gap of knowledge about ELAs and the learning outcomes that they address, including the transformative competencies and behavior change (UNESCO, 2014b).

\section{Conclusions}

Education and learning activities in ESD were grounded in discussions and reflections, starting with concrete problems or experiences, and were commonly not disciplinespecific, but rather interdisciplinary. They used participatory teaching methods and mainly relied on problem-based or experiential learning in accordance with UNESCO's recommendations. The activities were further characterized by teamwork and collaboration with stakeholders who also came from outside the university. While learning outcomes regularly enhanced knowledge, attitude, collaboration competencies, as well as critical and system thinking, self-awareness and behavior change were less commonly 
addressed. The studies addressing behavior frequently recognized inertia to behavior change, despite transferred attitudes and increased knowledge. Although UNESCO outlined behavioral learning objectives as particularly important for ESD, the present review revealed that these had hardly been reached by the used ELA. Understanding the complexity of behavior change, ethics-led whole-institution approaches seem to have greater potential to achieve actions and social activities towards SD. Future research and improvement initiatives should develop and evaluate ELAs with greater transformation potential by acknowledging the complexity of behavior change and by focusing on a whole institution approach as a core attribute to advance ESD, as recognized by the Global Action Programme at the World Conference on ESD in 2014 (UNESCO, 2014a).

\section{References}

Abner, M., Baytar, F., \& Kreiner, D. (2019). Applying the ESD approach in textile and apparel education. International Journal of Sustainability in Higher Education, 20(1), 75-90. doi: 10.1108/IJSHE-02-2018-0029

Altomonte, S., Logan, B., Feisst, M., Rutherford, P., \& Wilson, R. (2016). Interactive and situated learning in education for sustainability. International Journal of Sustainability in Higher Education, 17(3), 417-443. doi: 10.1108/IJSHE-01-20150003

Barth, M., \& Michelsen, G. (2013). Learning for change: An educational contribution to sustainability science. Sustainability Science, 8(1), 103-119. doi: 10.1007/s11625012-0181-5

Belluigi, D. Z., \& Cundill, G. (2017). Establishing enabling conditions to develop critical thinking skills: a case of innovative curriculum design in Environmental Science. Environmental Education Research, 23(7), 950-971. doi: 10.1080/13504622.2015. 1072802

Bruner, J. S. (1959). Learning and thinking. Harvard Educational Review, 29, 184192.

Burch, G. F., Giambatista, R., Batchelor, J. H., Burch, J. J., Hoover, J. D., \& Heller, N. A. (2019). A meta-analysis of the relationship between experiential learning and learning outcomes. Decision Sciences Journal of Innovative Education, 17(3), 239-273. doi: 10.1111/dsji.12188

Clark, W. C., \& Dickson, N. M. (2003). Sustainability science: The emerging research program. Proceedings of the National Academy of Sciences, $100(14), 8059$.

Dawe, G., Jucker, R., \& Martin, S. (2005). Sustainable development in higher education: Current practice and future developments. A report for the higher education academy. https://www.heacademy.ac.uk/system/files/sustdevinHEfinalreport.pdf

Dewey, J. (1929). The quest of certainty. New York: Minton.

DiClemente, C. C., \& Prochaska, J. O. (1982). Self-change and therapy change of smoking behavior: A comparison of processes of change in cessation and maintenance. Addictive Behaviors, 7(2), 133-142. https://doi.org/10.1016/0306-4603(82)90038-7

DiClemente, C. C., \& Prochaska, J. O. (1998). Toward a comprehensive, transtheoretical model of change: Stages of change and addictive behaviors. In Treating addictive behaviors, $2^{\text {nd }}$ ed. (pp. 3-24). New York, NY, US: Plenum Press. 
do Amaral, J. A. A., \& Hess, A. (2018). The WEBSIM FISHBANKS Simulation Laboratory: Analysis of its Ripple Effects. International Journal of Instruction, 11(2), 369-384. doi: 10.12973/iji.2018.11225a

Ellis, G., \& Weekes, T. (2008). Making sustainability 'real': Using group-enquiry to promote education for sustainable development. Environmental Education Research, 14(4), 482-500. doi: 10.1080/13504620802308287

Fazey, J., Schapke, N., Caniglia, G., Patterson, J., Hultman, J., van Mierlo, B., ... Wyborn, C. (2018). Ten essentials for action-oriented and second order energy transitions, transformations and climate change research. Energy Research \& Social Science, 40, 54-70. doi: 10.1016/j.erss.2017.11.026

Fischer, D., Aubrecht, E. L., Brück, M., Ditges, L., Gathen, L., Jahns, M., ... Wellmann, C. (2015). UN Global Action Programme and Education for Sustainable Development: A critical appraisal of the evidence base. Discourse and Communication for Sustainable Education, 6(1), 5-20.

Freud, S. (1959). The question of lay analysis. In J. Strachey (Ed.), The standard edition of the complete psychological works of Sigmund Freud (pp. 183-251). London: Hogarth Press.

Fry, H., Ketteridge, S., \& Marshall, S. (1999). A handbook of teaching and learning in higher education. London: Kogan Page Limited.

Gordon, S., \& Thomas, I. (2018). 'The learning sticks': Reflections on a case study of role-playing for sustainability. Environmental Education Research, 24(2), 172190. doi: 10.1080/13504622.2016.1190959

Harmoinen, S., Koivu, K., \& Pääsky, L. (2020). University students' readiness for social activity in climate actions. Discourse and Communication for Sustainable Education, 11(1), 134-152. doi: 10.2478/dcse-2020-0012

Heasly, B., Lindner, J., Iliško, D., \& Salìte, I. (2020). From initiatives, to insights, to implementation of the sustainability and securitability agenda for 2030. Discourse and Communication for Sustainable Education, 11(1), 1-4.

Heinrich, W. F., Habron, G. B., Johnson, H. L., \& Goralnik, L. (2015). Critical thinking assessment across four sustainability-related experiential learning settings. Journal of Experiential Education, 38(4), 373-393. doi: 10.1177/1053825915592890

Kolb, D. (1984). Experiential learning: Experience as the source of learning and development. NJ: Prentice Hall.

Kolb, D., \& Boyatzis, R. (2000). Experiential learning theory: Previous research and new directions. In R. Sternberg \& L. Shang (Eds.), Perspectives on cognitive, learning and thinking styles. NJ: Lawrence Erlbaum.

Mezirow, J. (1997). Transformative learning: Theory to practice. New Directions for Adult and Continuing Education, 74, 5-12.

Mintz, K., Talesnick, M., Amadei, B., \& Tal, T. (2014). Integrating sustainable development into a service-learning engineering course. Journal of Professional Issues in Engineering Education \& Practice, 140(1), 1. doi: 10.1061/(ASCE)EI.1943-5541. 0000169

Moher, D., Liberati, A., Tetzlaff, J., Altman, D. G., \& Group, a. t. P. (2009). Preferred reporting items for systematic reviews and meta-analyses: The PRISMA statement. Annals of Internal Medicine, 151(4), 264-269. doi: 10.7326/0003-4819-151-4200908180-00135 
Mulà, I., Tilbury, D., Ryan, A., Mader, M., Dlouhá, J., Mader, C., ... Alba, D. (2017). Catalysing change in higher education for sustainable development: A review of professional development initiatives for university educators. International Journal of Sustainability in Higher Education, 18(5), 798-820. doi: 10.1108/IJSHE-032017-0043

Paige, K. (2017). Educating for sustainability: Environmental pledges as part of tertiary pedagogical practice in science teacher education. Asia-Pacific Journal of Teacher Education, 45(3), 285-301. doi: 10.1080/1359866X.2016.1169504

Pipere, A. (2019). Journal of Teacher Education for Sustainability after the UN Decade of Education for Sustainable Development: Exploring for the future. Journal of Teacher Education for Sustainability, 21(1), 5-34.

Rogers, C. (1951). Client-centered therapy. Boston: Hougthon-Mifflin.

Salite, I. (2016). Searching for sustainability in teacher education and educational research: Experiences from the Baltic and Black Sea Circle Consortium for educational research. Discourse and Communication for Sustainable Education, 6(1), 21-29.

Sipos, Y., Battisti, B., \& Grimm, K. (2008). Achieving transformative sustainability learning: Engaging head, hands and heart. International Journal of Sustainability in Higher Education, 9(1), 68-86. http://dx.doi.org/10.1108/14676370810842193

Skinner, B. (1971). Beyond freedom and dignity. New York: Bantam/Vintage.

UNESCO. (2014a). Roadmap for implementing the Global Action Programme on Education for Sustainable Development. Paris: UNESCO publishing.

UNESCO. (2014b). Shaping the future we want: UN Decade for Sustainable Development (2005-2014) Final Report, DESD Monitoring and Evaluation. Paris: UNESCO.

UNESCO. (2017). Education for sustainable development goals: Learning objectives. Paris, France: UNESCO

UNESCO. (2018). United Nations Educational, Scientific and Cultural Organization (UNESCO). Issues and trends in Education for Sustainable Development. Paris, France: UNESCO.

Vardi, I., \& Ciccarelli, M. (2008). Overcoming problems in problem-based learning: A trial of strategies in an undergraduate unit. Innovations in Education and Teaching International, 45(4), 345-354.

Wals, A. E. J., \& Jickling, B. (2002). "Sustainability” in higher education: From doublethink and newspeak to critical thinking and meaningful learning. Higher Education Policy, 15(2), 121-131. https://doi.org/10.1016/S0952-8733(02)00003-X

Wiek, A., Withycombe, L., \& Redman, C. L. (2011). Key competencies in sustainability: A reference framework for academic program development. Sustainability Science, 6(2), 203-218. doi: 10.1007/s11625-011-0132-6

Wiek, A., Xiong, A., Brundiers, K., \& van der Leeuw, S. (2014). Integrating problemand project-based learning into sustainability programs. A case study on the School of Sustainability at Arizona State University. International Journal of Sustainability in Higher Education, 15(4), 431-449. doi: 10.1108/ijshe-02-2013-0013

Correspondence concerning this paper should be addressed to Beatrix Algurén, Faculty of Education, Department of Food and Nutrition, and Sport Science, University of Gothenburg, PO Box 300, 40530 Gothenburg Phone: +46 (0)31-786 4218, Fax +46 (0)31-786 2048. Email: Beatrix.alguren@gu.se 


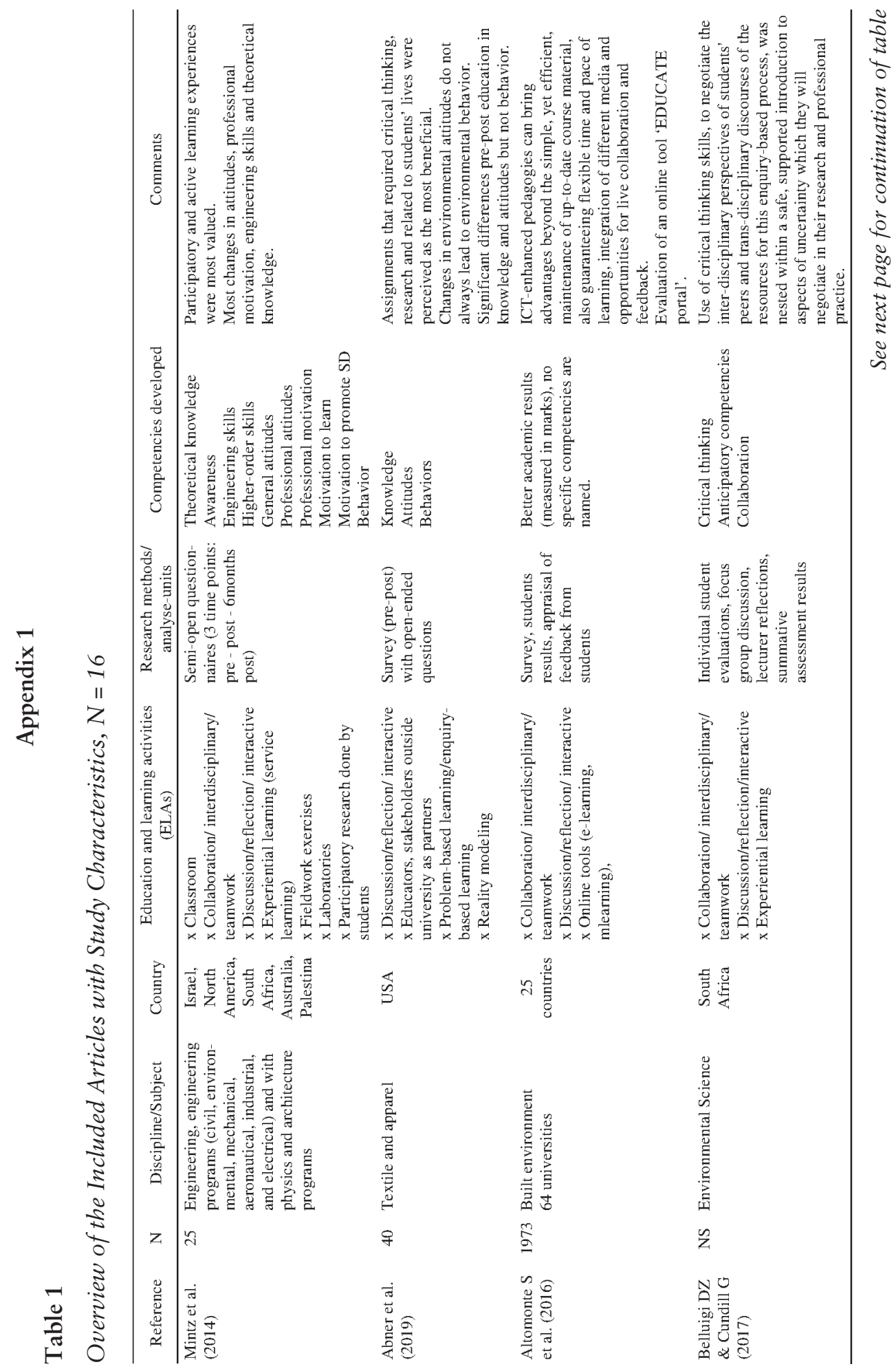




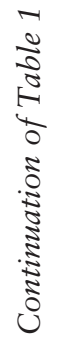

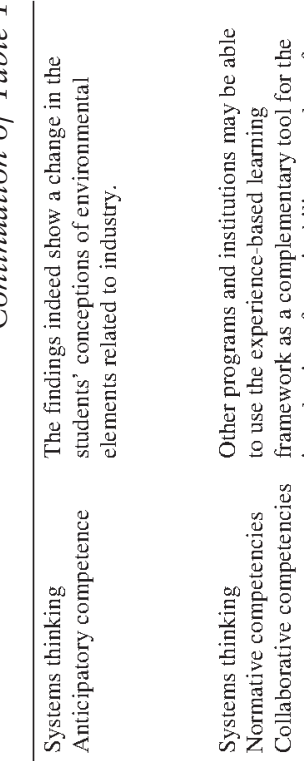

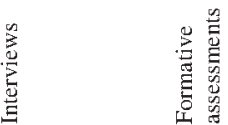

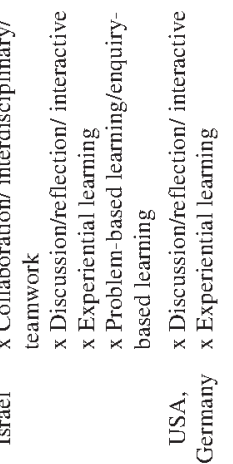

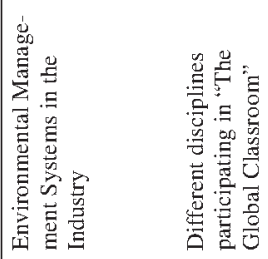

으

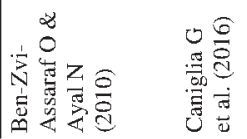

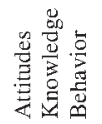

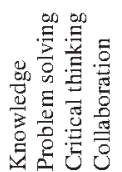

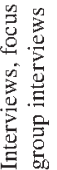

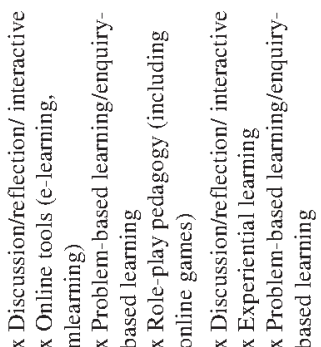

畨

当

言离

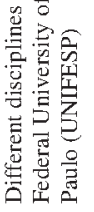

8

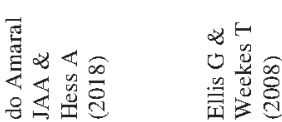
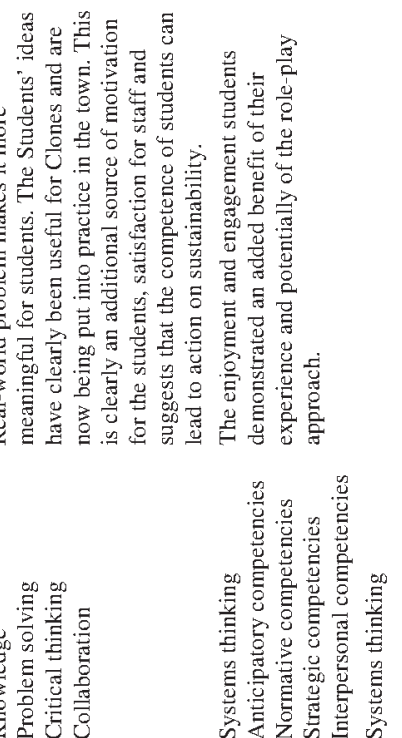

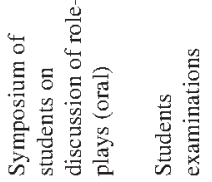
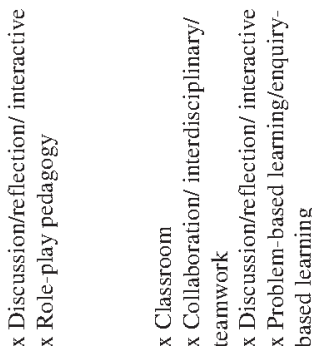

苞
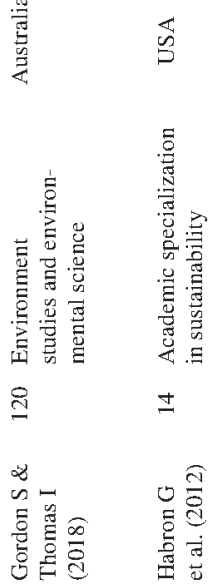

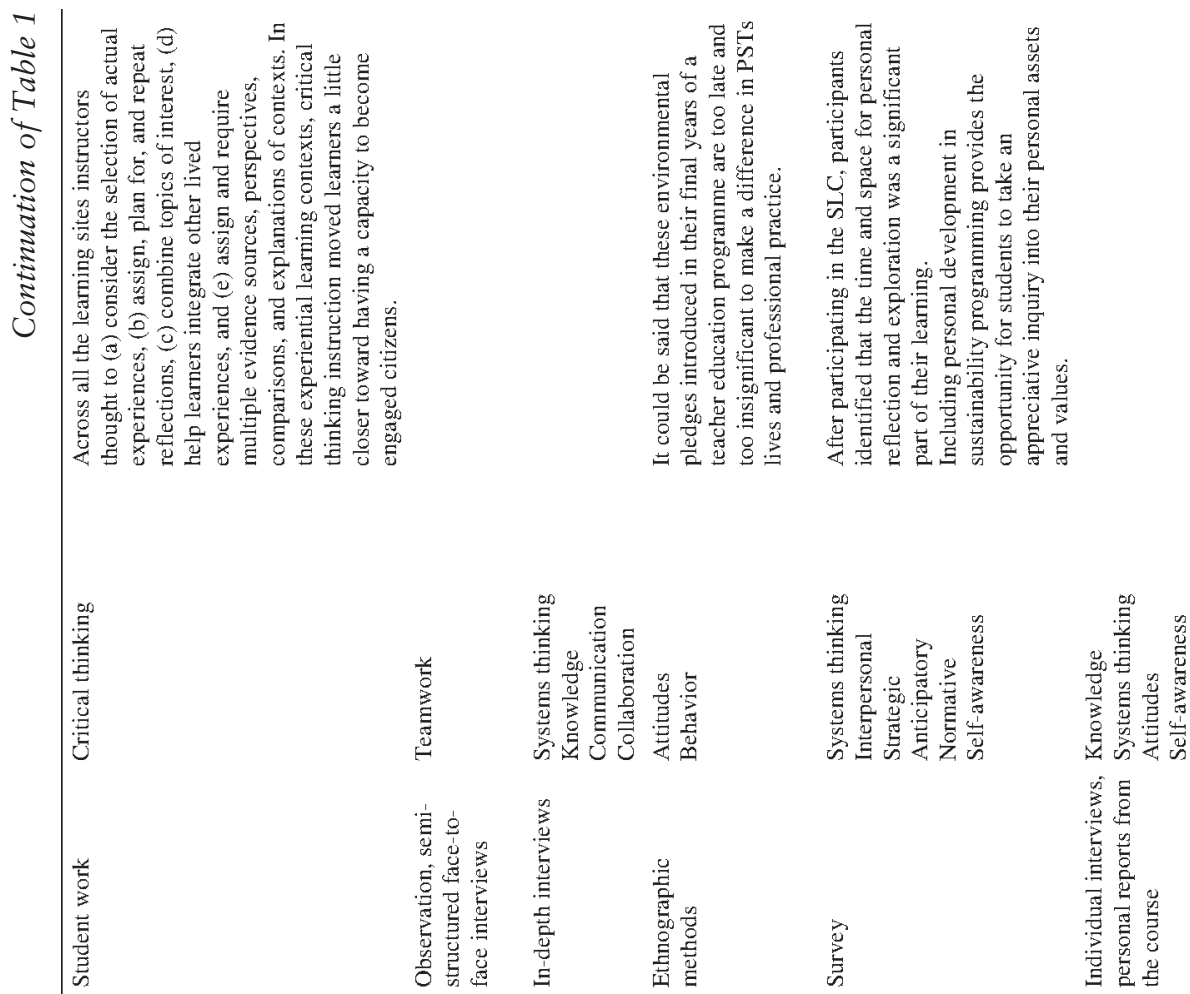

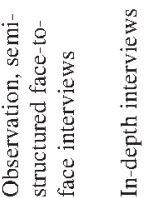

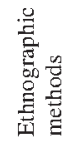

$$
\text { 总 }
$$
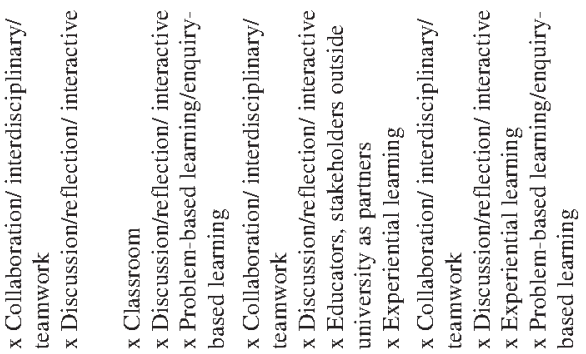

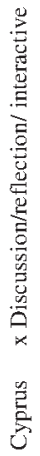

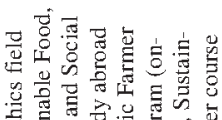

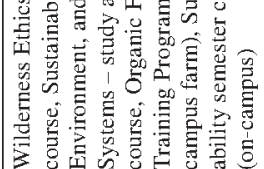

苛

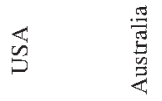

莺

节.

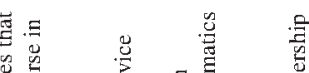

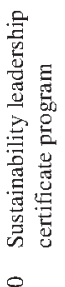

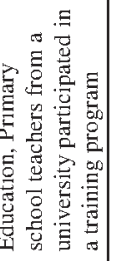

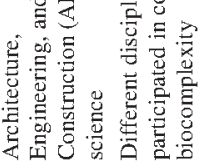

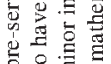

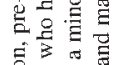

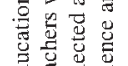

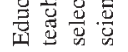

\&

$\stackrel{n}{2}$

点合

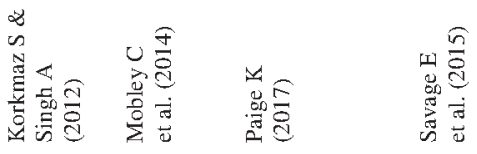

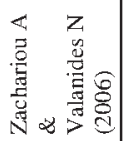

